\title{
Particle number concentrations over Europe in 2030: the role of emissions and new particle formation
}

\author{
L. Ahlm ${ }^{1}$, J. Julin ${ }^{1}$, C. Fountoukis ${ }^{2}$, S. N. Pandis ${ }^{2,3,4}$, and I. Riipinen ${ }^{1}$ \\ ${ }^{1}$ Department of Applied Environmental Science (ITM) and the Bert Bolin Centre for Climate Research (BBCC), \\ Stockholm University, Stockholm, Sweden \\ ${ }^{2}$ Institute of Chemical Engineering Sciences, Foundation for Research and Technology Hellas (ICEHT/FORTH), \\ Patras, Greece \\ ${ }^{3}$ Department of Chemical Engineering, Carnegie Mellon University, Pittsburgh, PA, USA \\ ${ }^{4}$ Department of Chemical Engineering, University of Patras, Patras, Greece
}

Correspondence to: L. Ahlm (lars.ahlm@itm.su.se)

Received: 12 March 2013 - Published in Atmos. Chem. Phys. Discuss.: 3 April 2013

Revised: 5 September 2013 - Accepted: 13 September 2013 - Published: 22 October 2013

\begin{abstract}
The aerosol particle number concentration is a key parameter when estimating impacts of aerosol particles on climate and human health. We use a three-dimensional chemical transport model with detailed microphysics, PMCAMxUF, to simulate particle number concentrations over Europe in the year 2030, by applying emission scenarios for trace gases and primary aerosols. The scenarios are based on expected changes in anthropogenic emissions of sulfur dioxide, ammonia, nitrogen oxides, and primary aerosol particles with a diameter less than $2.5 \mu \mathrm{m}\left(\mathrm{PM}_{2.5}\right)$ focusing on a photochemically active period, and the implications for other seasons are discussed.

For the baseline scenario, which represents a best estimate of the evolution of anthropogenic emissions in Europe, PMCAMx-UF predicts that the total particle number concentration $\left(N_{\text {tot }}\right)$ will decrease by $30-70 \%$ between 2008 and 2030. The number concentration of particles larger than $100 \mathrm{~nm}\left(N_{100}\right)$, a proxy for cloud condensation nuclei $(\mathrm{CCN})$ concentration, is predicted to decrease by $40-70 \%$ during the same period. The predicted decrease in $N_{\text {tot }}$ is mainly a result of reduced new particle formation due to the expected reduction in $\mathrm{SO}_{2}$ emissions, whereas the predicted decrease in $N_{100}$ is a result of both decreasing condensational growth and reduced primary aerosol emissions. For larger emission reductions, PMCAMx-UF predicts reductions of $60-80 \%$ in both $N_{\text {tot }}$ and $N_{100}$ over Europe.
\end{abstract}

Sensitivity tests reveal that a reduction in $\mathrm{SO}_{2}$ emissions is far more efficient than any other emission reduction inves- tigated, in reducing $N_{\text {tot }}$. For $N_{100}$, emission reductions of both $\mathrm{SO}_{2}$ and $\mathrm{PM}_{2.5}$ contribute significantly to the reduced concentration, even though $\mathrm{SO}_{2}$ plays the dominant role once more. The impact of $\mathrm{SO}_{2}$ for both new particle formation and growth over Europe may be expected to be somewhat higher during the simulated period with high photochemical activity than during times of the year with less incoming solar radiation.

The predicted reductions in both $N_{\text {tot }}$ and $N_{100}$ between 2008 and 2030 in this study will likely reduce both the aerosol direct and indirect effects, and limit the damaging effects of aerosol particles on human health in Europe.

\section{Introduction}

Atmospheric aerosol particles impact the Earth's energy balance directly by absorbing and scattering solar radiation, and indirectly by acting as cloud condensation nuclei $(\mathrm{CCN})$, thereby modifying the optical properties of clouds (Twomey et al., 1977) as well as their lifetime (Albrecht et al., 1989). The radiative forcing associated with the indirect effect of anthropogenic aerosols has the largest uncertainty of all forcing mechanisms estimated by the Intergovernmental Panel on Climate Change (IPCC) for the industrial period (IPCC, 2007). Aerosols also affect human health, as exposure to aerosols is associated with damaging effects on 
the respiratory and cardiovascular systems (Davidson et al., 2005; Pope and Dockery, 2006).

Most previous aerosol modelling studies have focused on the simulation of particle mass rather than particle number (e.g. Wexler et al., 1994; Pilinis et al., 2000; Schell et al., 2001; Simpson et al., 2007; Bessagnet et al., 2009; Fountoukis et al., 2011). In many locations aerosols are regulated by particle mass, for instance $\mathrm{PM}_{2.5}$ (mass concentration of particles with diameter $\left(D_{\mathrm{p}}\right)$ lower than $\left.2.5 \mu \mathrm{m}\right)$. However, results from several studies indicate that ultrafine particles $\left(D_{\mathrm{p}}<100 \mathrm{~nm}\right)$, which in most cases dominate the particle number concentration but only make a minor contribution to the particle mass, may cause particularly adverse health effects (e.g. Oberdörster et al., 1996; Peters et al., 1997). The particle number size distribution is highly relevant also when determining aerosol impacts on climate, since it gives an estimate of the concentration of cloud condensation nuclei $(\mathrm{CCN})$. Thus, to estimate the influence of aerosol particles on both climate and human health, it is necessary to know the particle number size distribution.

Aerosol particles may be emitted directly (primary particles) or form in the atmosphere by homogeneous nucleation (secondary particles). The fresh particles can then grow through condensation of vapours (e.g. sulfuric acid, ammonia and organics) and reach a size where they can have an impact on climate. For aerosol particles to be able to act as $\mathrm{CCN}$ in the atmosphere, they must have a diameter larger than 40-120 nm, depending on their hygroscopicity, and the ambient water supersaturation (Dusek et al., 2006).

The primary vapour responsible for atmospheric nucleation is thought to be sulfuric acid (e.g. Riipinen et al., 2007). However, proposed nucleation mechanisms differ in terms of which gas-phase species assist sulfuric acid $\left(\mathrm{H}_{2} \mathrm{SO}_{4}\right)$ in forming the critical cluster. In the most common binary nucleation scheme, it is assumed that the critical cluster is composed by $\mathrm{H}_{2} \mathrm{O}$ and $\mathrm{H}_{2} \mathrm{SO}_{4}$. Binary nucleation of water and sulfuric acid may be significant in the upper troposphere and lower stratosphere (Adams and Seinfeld, 2002), but generally underpredicts nucleation rates in the lower troposphere (Kulmala et al., 2004). Nucleation involving sulfuric acid is known to be favoured by the presence of species such as ammonia $\left(\mathrm{NH}_{3}\right)$ (Coffman and Hegg, 1995; Ball et al., 1999), amines (Murphy et al., 2007; Smith et al., 2010), or organic compounds (Paasonen et al., 2010; Riccobono et al., 2012). The presence of ions is also expected to enhance nucleation rates (Raes et al., 1986; Lovejoy et al., 2004; Sorokin and Arnold, 2007). Kirkby et al. (2011) showed that atmospherically relevant $\mathrm{NH}_{3}$ mixing ratios of $100 \mathrm{ppt}$, or less, increase the nucleation rate of sulfuric acid particles by more than a factor of 100-1000. However, they also concluded that atmospheric concentrations of ammonia and sulfuric acid are sometimes too low to explain the observed boundary layer nucleation. Nonetheless, Jung et al. (2010) successfully predicted frequent nucleation events and measured number concentrations in the north-eastern United States using the regional model PMCAMx-UF with a scaled version of the ternary $\mathrm{H}_{2} \mathrm{SO}_{4}-\mathrm{NH}_{3}-\mathrm{H}_{2} \mathrm{O}$ nucleation parameterization of Napari et al. (2002).

The formation rate of new particles has in several studies been observed to be proportional to sulfuric acid concentration with a power of 1 to 2 (Weber et al., 1995; Sihto et al., 2006; Riipinen et al., 2007; Kuang et al., 2008). The power one-dependence has been described in terms of an activation theory (Kulmala et al., 2006), whereas the power twodependence has been described in terms of a kinetic nucleation mechanism (McMurry and Friedlander, 1979). Fountoukis et al. (2012) compared a scaled version of the ternary $\mathrm{H}_{2} \mathrm{SO}_{4}-\mathrm{NH}_{3}-\mathrm{H}_{2} \mathrm{O}$ nucleation parameterization of Napari et al. (2002) with activation and kinetic nucleation parameterizations, using PMCAMx-UF, and found that the ternary nucleation parameterization performed best in reproducing particle number concentration observations in Europe. Even though amines could potentially play a more important role than ammonia in nucleation, concentrations of amines and ammonia can in most conditions be expected to be correlated which means that a scaled ternary $\mathrm{H}_{2} \mathrm{SO}_{4}-\mathrm{NH}_{3}-\mathrm{H}_{2} \mathrm{O}$ nucleation parameterization may account also for a potential role of amines at least to some extent.

Makkonen et al. (2012) used the global climate model ECHAM5-HAM to simulate aerosol concentrations, cloud properties and total aerosol forcing with emissions representing the years 2000 and 2100 . They found that the strong expected reduction in anthropogenic $\mathrm{SO}_{2}$ emissions would lead to less aerosol nucleation resulting in particle number concentration reductions by $50-90 \%$ in Europe, North America, and eastern China. The following suppression of future aerosol forcing would lead to an even larger warming of climate than expected based on increased greenhouse gas concentrations. Kloster et al. (2008) used a global model with emission scenarios provided by the International Institute for Applied Systems Analysis (IIASA), and nucleation being represented by a binary $\mathrm{H}_{2} \mathrm{SO}_{4}-\mathrm{H}_{2} \mathrm{O}$ scheme, and found that the anthropogenic aerosol forcing could be more than halved by 2030 because of aerosol reduction policies. Stier et al. (2006) predicted the global mean sulfate concentration to peak in 2020 and thereafter to decrease based on simulations with an SRES A1B emission scenario applied to a general circulation model. Lamarque et al. (2011) predicted the globally averaged aerosol optical depth to decrease after 2000 , mainly as a result of an expected strong decrease in anthropogenic $\mathrm{SO}_{2}$ emissions.

If new particle formation is controlled to a large extent by atmospheric concentrations of $\mathrm{H}_{2} \mathrm{SO}_{4}$ and $\mathrm{NH}_{3}$, future scenarios of emissions of these species are critical when predicting future particle number concentrations. The International Institute for Applied Systems Analysis (IIASA) developed future anthropogenic emission scenarios for Europe based on the latest expectations on economic development and the implementation of recent policies on energy, transport, agriculture, and climate change (Amann et al., 2012). 
These emission scenarios include $\mathrm{SO}_{2}, \mathrm{NH}_{3}$, nitrogen oxides $\left(\mathrm{NO}_{\mathrm{x}}\right)$, and $\mathrm{PM}_{2.5}$. According to the IIASA baseline scenario, which represents a best estimate of future emissions, $\mathrm{SO}_{2}$ emissions are predicted to decrease by $\sim 70 \%$ in Europe between 2008 and 2030, with the largest reductions expected in the power sector. According to the same scenario and in the same period, $\mathrm{NH}_{3}$ emissions are predicted to stay nearly constant, as a result of almost unchanged emissions from cattle farming which is the largest source of $\mathrm{NH}_{3} . \mathrm{PM}_{2.5}$ and $\mathrm{NO}_{\mathrm{x}}$ emissions are expected to drop by $40 \%$ and $65 \%$, respectively. The decline in $\mathrm{PM}_{2.5}$ emissions is primarily due to stricter standards for diesel vehicles, while the decline in $\mathrm{NO}_{\mathrm{x}}$ emissions would mainly follow from more stringent controls of new vehicles and power plants. In addition to the baseline scenario, IIASA developed scenarios exploring possible additional emission reductions that would result from full application of available technical measures, decarbonisation, and a change of behaviour resulting in diets that include less meat. These latter scenarios result in larger reductions of $\mathrm{SO}_{2}, \mathrm{PM}_{2.5}$, and $\mathrm{NO}_{\mathrm{x}}$ emissions than predicted by the baseline scenario, and they also include significant decreases in $\mathrm{NH}_{3}$ emissions. In this study we use the regional chemical transport model PMCAMx-UF with detailed microphysics to predict how emissions based on the IIASA future scenarios may affect particle number concentrations over Europe in the year 2030.

Fountoukis et al. (2012) applied PMCAMx-UF to the European domain to simulate particle number concentrations for May 2008. That model simulation was compared with number concentration observations during the European Aerosol Cloud Climate and Air Quality Interactions (EUCAARI) project (Kulmala et al., 2011) at seven different sites in Europe. They found that PMCAMx-UF, using the scaled version of the ternary $\mathrm{H}_{2} \mathrm{SO}_{4}-\mathrm{NH}_{3}-\mathrm{H}_{2} \mathrm{O}$ nucleation parameterization of Napari et al. (2002), reproduced more than $70 \%$ of the data points for number concentrations of particles larger than $10 \mathrm{~nm}\left(N_{10}\right)$, and particles larger than $50 \mathrm{~nm}$ $\left(N_{50}\right)$ within a factor of 2 , at the seven locations. Number concentrations of particles larger than $100 \mathrm{~nm}\left(N_{100}\right)$ were somewhat underestimated, partly due to lack of organic contribution to particle growth in the model.

Here we use PMCAMx-UF with the same set-up as the one used by Fountoukis et al. (2012) to predict particle number concentrations over Europe in the year 2030. We investigate what particle size ranges are associated with the largest changes in concentration, and also whether changes in primary aerosol emissions or changes in new particle formation will be the most important factor for the overall change in particle number concentration over Europe. Finally, we explore what emission reductions are most effective in reducing number concentrations over Europe.

\section{Model description}

PMCAMx-UF is a three-dimensional chemical transport model (CTM) with detailed microphysics simulating both the particle number size distribution and the mass/composition size distribution. A detailed description of PMCAMx-UF can also be found in Jung et al. (2010) and Fountoukis et al. (2012). PMCAMx-UF was based on PMCAMx (Gaydos et al., 2007) which focuses on the simulation of the mass distribution of PM. The PMCAMx-UF algorithms used for the simulation of horizontal and vertical advection, horizontal and vertical diffusion, wet and dry deposition, and gas-phase chemistry, are identical to those used in PMCAMx. However, PMCAMx-UF uses the DMAN model (Jung et al., 2006) to simulate the aerosol processes (nucleation, coagulation, condensation/evaporation, and emissions) assuming that the aerosol is internally mixed. DMAN tracks both the aerosol number and mass size distributions by applying the TwoMoment-Aerosol Sectional (TOMAS) algorithm of Adams and Seinfeld (2002). The aerosol size distributions are discretized in 41 size bins, covering the diameter range from $0.8 \mathrm{~nm}$ to $10 \mu \mathrm{m}$. For the $10-40 \mu \mathrm{m}$ diameter range, two additional size bins are used for the description of cloud chemistry.

The aerosol compounds included in PMCAMx-UF include primary organic aerosol, four secondary organic aerosol components, elementary carbon, crustal material, water, chloride, sodium, ammonium, nitrate, and sulfate. The primary organic aerosol is assumed to be non-volatile. The TOMAS version currently used in PMCAMx-UF explicitly tracks sulfate, ammonium, and water, while the rest of the species are lumped into one surrogate species that is assumed to be inert. For aqueous-phase chemistry, the approach of Fahey and Pandis (2001) is used.

The simulation of nucleation in PMCAMx-UF is based on the parameterization of Napari et al. (2002) for ternary $\mathrm{H}_{2} \mathrm{SO}_{4}-\mathrm{NH}_{3}-\mathrm{H}_{2} \mathrm{O}$ nucleation. Since this parameterization has been shown to overpredict the production of ultrafine particles during new particle formation events (Gaydos et al., 2005; Yu et al., 2006a, b; Jung et al., 2006; Merikanto et al., 2007; Zhang et al., 2010), a scaling factor of $10^{-6}$ is applied to the nucleation rates in PMCAMx-UF (Fountoukis et al., 2012). While the parameterization of Napari et al. (2002) might not provide the right mechanistic picture, it may still be a reasonable approximation due to ammonia being a tracer for other bases, e.g. amines.

Nucleation and condensation rates are calculated simultaneously using the pseudo-steady-state approximation (PSSA) for sulfuric acid proposed by Pierce and Adams (2009) which assumes that the sulfuric acid concentration reaches steady state instantaneously during a time step. The TOMAS algorithm is used for the simulation of condensation/evaporation of sulfuric acid and ammonia, and the two species are treated independently. For sulfuric acid condensation, the $\mathrm{H}_{2} \mathrm{SO}_{4}$ mass added to each section is calculated 
as well as its total concentration. The mass distributed in each section is used to calculate the driving force for the $\mathrm{H}_{2} \mathrm{SO}_{4}$ condensation (Adams and Seinfeld, 2002). Condensation of ammonia is simulated in the same way as in Gaydos et al. (2005), assuming an accommodation coefficient of 0.08 (Shi et al., 2009; Swartz et al., 1999) and that its surface vapour pressure over the acidic particles is equal to zero. Organic vapours contribute very little to the growth of the ultrafine particles due to their assumed high saturation concentrations of the secondary organic aerosol components. This means that particle growth rates in this study are underestimated in some areas. Fountoukis et al. (2012) found that the modelled growth rates were $20-70 \%$ lower than the observed values at different sites over Europe, which implies that PMCAMx-UF somewhat underestimates the $N_{100}$ concentrations.

The TOMAS algorithm is used also for the simulation of coagulation with prognostic equations for both aerosol mass and number concentrations in each size bin. The calculation of the coagulation coefficients follows the approach of Gaydos et al. (2007).

\section{PMCAMx-UF application}

The PMCAMx-UF modelling domain over Europe covers a $5400 \times 5832 \mathrm{~km}^{2}$ region with 150 cells in the $x$ - and 162 cells in the $y$ direction, with a $36 \times 36 \mathrm{~km}$ grid resolution and 14 vertical layers covering approximately $20 \mathrm{~km}$ in the $z$ direction (Fountoukis et al., 2012). PMCAMx-UF performs simulations on a rotated polar stereographic map projection. The first two days of each simulation have been excluded from the results to be presented, in order to limit the effect of the initial conditions on the results.

\subsection{Meteorological input}

The meteorological input to PMCAMx-UF in this study is identical to the input used by Fountoukis et al. (2012), and includes horizontal wind components, vertical diffusivity, temperature, pressure, water vapour, clouds, and rainfall. The meteorological model WRF (Skamarock et al., 2005) was used to create these inputs that represent May 2008. WRF is driven by static geographical data and dynamic meteorological data, including 27 sigma-p layers up to 0.1 bars in the vertical dimension. Each layer of PMCAMx-UF is aligned with the layers used in WRF. The WRF May 2008 run was re-initialized every third day to ensure accuracy in all fields used as input in PMCAMx-UF.

\subsection{Emissions}

Emissions for May 2008 are the same as in Fountoukis et al. (2012). Hourly gridded emissions developed for the European region include both primary particulate matter and trace gases. The Pan-European anthropogenic Particle Number
Emission Inventory (Denier van der Gon et al., 2009; Kulmala et al., 2011) was used for particle emissions in the diameter range 10-300 nm, and the Pan-European Carbonaceous Aerosol Inventory provided emissions of larger particles (Kulmala et al., 2011). The merged inventory includes both number emissions and consistent size-resolved composition for particles over the full modelled size range of $1 \mathrm{~nm}$ to $10 \mu \mathrm{m}$. Anthropogenic gas emissions that were used to develop the gridded fields include land emissions from the GEMS data set (Visschedijk et al., 2007), as well as international shipping emissions. The anthropogenic emission sources include traffic, industrial, domestic, agricultural, etc. sources.

In this study we explore three of the future emission scenarios described in the IIASA report (Amann et al., 2012). All emission scenarios analysed represent projections to the year 2030. The three scenarios are: (1) a baseline scenario; (2) a Maximum Technically Feasible Reduction (MTFR) scenario; and (3) a Maximum Control Efforts (MCE) scenario.

The baseline scenario represents a prediction of emissions in 2030 by assuming full implementation of existing air pollution control legislation in the European Union. The MTFR scenario explores to what extent emissions could be further reduced through full application of available technical measures. The MCE scenario explores the ultimate emission reductions that could be achieved through rapid decarbonisation, application of all available air pollution control technologies, and a change of diets to include less meat. Thus, whereas the baseline scenario represents the most likely scenario, the two other scenarios explore what additional emission reductions are possible. A more detailed description of these emission scenarios can be found in Amann et al. (2012). Table 1 shows the reductions in $\mathrm{SO}_{2}, \mathrm{NH}_{3}, \mathrm{NO}_{\mathrm{x}}$, and $\mathrm{PM}_{2.5}$ from 2008 to 2030 for each of the three scenarios.

For the emission scenarios in this study we assume the same percentage change in emissions of trace gases and $\mathrm{PM}_{2.5}$ for all model grid cells within the European domain. Hence, we do not consider any spatial variations in the change of emissions for any of the scenarios. The reasons for this simplification are that all the emission scenarios do not have emissions separated by country in Amann et al. (2012) and that the analysis of the changes is simplified by the use of a constant fraction. The concentrations at the boundaries of the model area were not changed for the different scenarios. We also assume that the $\mathrm{PM}_{2.5}$ emissions are reduced uniformly for all size bins (smaller than $2.5 \mu \mathrm{m}$ ) for each scenario.

\section{Results and discussion}

All simulations in this study were performed with meteorological input from May 2008 and with the same boundary concentrations of aerosols and trace gases for each 
Table 1. Percentage change in emissions between 2008 and 2030 in the European Union.

\begin{tabular}{lrrrr}
\hline & $\mathrm{SO}_{2}$ & $\mathrm{NH}_{3}$ & $\mathrm{PM}_{2.5}$ & $\mathrm{NO}_{\mathrm{x}}$ \\
\hline Baseline & -73 & 0 & -38 & -66 \\
MTFR & -82 & -30 & -69 & -75 \\
MCE & -85 & -40 & -74 & -90 \\
\hline
\end{tabular}

simulation. Hence, differences in output concentrations between the performed simulations are due only to changes in European emissions. The fact that we use meteorological input from May 2008 for our simulations of the 2030 scenarios implies that we neglect any changes in climate during this period. All atmospheric concentrations to be discussed represent surface concentrations. The time period that is simulated is 1-29 May, but as mentioned in Sect. 2 the first two days have been excluded from the analysis.

\subsection{Spatial distribution of particle number concentrations}

\subsubsection{Spatial distribution of $N_{\text {tot }}$ and $N_{10}$}

Figure 1a shows arithmetic mean values of the total particle number concentration $\left(N_{\text {tot }}\right)$ for each grid cell throughout the whole simulation period with the default emissions (May 2008) used. As discussed by Fountoukis et al. (2012), PMCAMx-UF predicts high number concentrations over large areas of eastern Europe during this photochemically active period. Locally, the model gives mean number concentrations of $50000 \mathrm{~cm}^{-3}$ or higher in these areas (Fig. 1a). High concentrations, $20000-50000 \mathrm{~cm}^{-3}$, are also predicted over Spain and Portugal. The lowest concentrations are found over the Nordic countries.

Figure $1 \mathrm{~b}$ shows the corresponding mean concentration map for the simulation of the baseline scenario in 2030 . Comparing Fig. 1b with Fig. 1a, it becomes clear that number concentrations in most places are expected to decrease significantly in Europe between 2008 and 2030, since both emissions of trace gases and $\mathrm{PM}_{2.5}$ in this simulation have been reduced. The concentrations are predicted to remain highest over eastern Europe, even though the values in general are considerably lower than those predicted for 2008. The fact that the spatial variations in number concentrations (Fig. 1b) are similar to those obtained in the simulation of May 2008 (Fig. 1a) is reasonable since the relative emission reductions have been assumed to be equal for all grid cells.

The percentage reduction in $N_{\text {tot }}$ for the baseline scenario (Fig. 2a) in general ranges from $30 \%$ to $70 \%$ over continental Europe with smaller reductions over the lowconcentration areas in the Nordic countries. Even though the general pattern in Fig. $2 \mathrm{a}$ is decreasing total number concentrations, there are enhancements of $N_{\text {tot }}$, for instance over parts of Great Britain, Belgium and Greece. Since primary
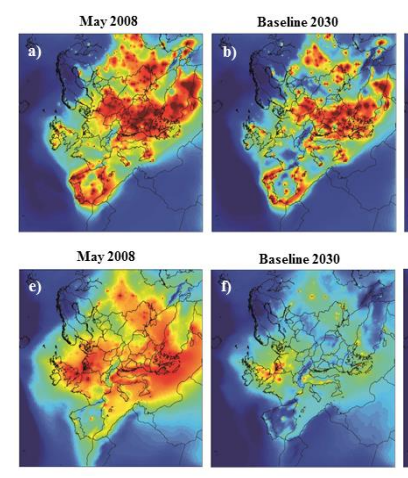

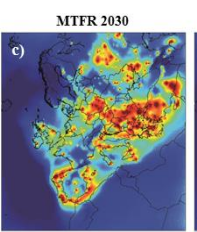

MITR 2030

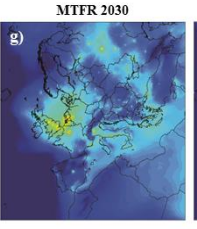

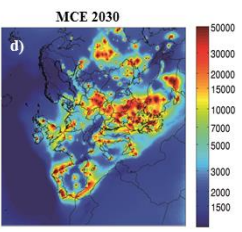

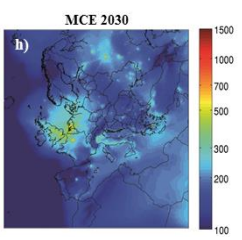

Fig. 1. Model simulations for 2008 and the baseline, MTFR, and MCE scenarios for 2030 for $N_{\text {tot }}(\mathbf{a}-\mathbf{d})$, and $N_{100}(\mathbf{e}-\mathbf{h})$. The concentrations are mean values in each grid cell for the whole simulation period. The colour bars indicate particle number concentration in $\# \mathrm{~cm}^{-3}$.

aerosol emissions have been reduced in the simulation of the baseline scenario (Table 1), the areas of increasing total number concentrations in Fig. 2a are associated with enhanced new particle formation due to a reduced condensation sink following from the reduction in concentrations of primary particles. In contrast to Fig. 2a, there are no areas associated with increasing concentrations in Fig. $2 \mathrm{~d}$ which shows the percentage change $N_{10}$. Instead Fig. $2 d$ indicates a more horizontally homogeneous reduction in the 20-60\% range. Hence, even though new particle formation may be predicted to increase the total number concentration in some areas in the baseline scenario, most of these particles are not predicted to reach sizes larger than $10 \mathrm{~nm}$.

For the MTFR scenario in 2030 (Fig. 1c), the mean decrease in total number concentration is larger than for the baseline scenario, as a result of the corresponding larger emission reductions (Table 1). For this scenario, PMCAMxUF predicts a reduction in $N_{\text {tot }}$ of more than $60 \%$ over large areas in eastern Europe, Spain, and France (Fig. 2b). Over the rest of continental Europe, the MTFR scenario in general results in a 30-50\% decrease in number concentration. However, also for this scenario there are some areas where the total number concentration is predicted to increase. The extent of this rather counterintuitive change is smaller than for the baseline scenario. Similar to the baseline scenario, the percentage reduction in $N_{10}$ (Fig. 2e) is more spatially uniform than for $N_{\text {tot }}$ and there are no areas where $N_{10}$ is predicted to increase.

The MCE 2030 scenario gives the largest decrease in $N_{\text {tot }}$ of all three scenarios (Fig. 1d) with a predicted decrease in $N_{\text {tot }}$ of 50-80\% over most of continental Europe (Fig. 2c), but locally more than $80 \%$ over eastern Europe. There are fewer areas with enhanced concentrations than in the baseline and MTFR scenarios, but they still exist mainly over Great Britain, Belgium and northern France. For $N_{10}$ 

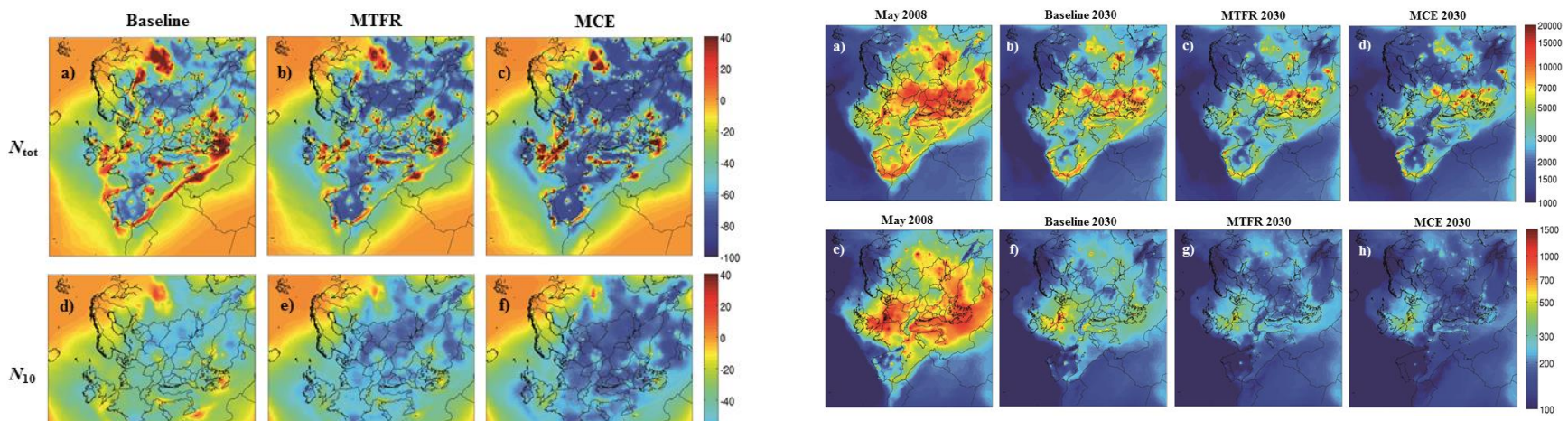

Fig. 3. Model simulations for 2008 and the baseline, MTFR, and MCE scenarios for 2030 for $N_{\text {tot }}(\mathbf{a}-\mathbf{d})$, and $N_{100}(\mathbf{e}-\mathbf{h})$. The concentrations are median values in each grid cell for the whole simulation period. The colour bars indicate particle number concentration in $\# \mathrm{~cm}^{-3}$.

\subsubsection{Spatial distribution of $N_{100}$}

Fig. 2. Predicted percentage change in mean concentration from 2008 to 2030 for the three future scenarios for $N_{\text {tot }}(\mathbf{a}-\mathbf{c}), N_{10}(\mathbf{d}-\mathbf{f})$, and $N_{100}(\mathbf{g}-\mathbf{i})$.

(Fig. 2f), the MCE scenario results in a reduction of 50-80\% over continental Europe.

These obtained $N_{\text {tot }}$ reductions of $30-80 \%$ for the baseline, MTFR, and MCE scenarios are similar to the 50-90\% reductions in total particle number concentrations predicted by Makkonen et al. (2012) for the period 2000-2100 over Europe using the global model ECHAM5-HAM. In those simulations the assumed emission reductions for the period 20002100 were $80 \%$ for $\mathrm{SO}_{2}, 50 \%$ for black carbon, and $30 \%$ for organic carbon, which are similar reductions to those assumed here (listed in Table 1).

Figure 3 shows median number concentrations for each grid cell throughout the whole simulation period for $N_{\text {tot }}$ and $N_{100}$. The median number concentrations for $N_{\text {tot }}$ (Fig. 3a, d) are considerably lower than the corresponding mean arithmetic mean concentrations in (Fig. 1a, d). Whereas the predicted mean number concentrations for May 2008 (Fig. 1a) reach over $50000 \mathrm{~cm}^{-3}$ in some locations, the corresponding median concentrations do not exceed $20000 \mathrm{~cm}^{-3}$ (Fig. 3a). The reason for this is that the mean value is more sensitive to extreme values than the median value. Therefore, strongly elevated concentrations resulting from e.g. nucleation events may have a high impact on the mean concentration while the corresponding impact on the median value is lower, unless the events occur with high frequency and last for a long time. For $N_{100}$, the differences between the mean and median values are much smaller. The reason for this is that nucleation has a much lower impact on $N_{100}$ than on $N_{\text {tot }}$.
Figure 1e shows the model prediction of mean concentrations of particles with a diameter larger than $100 \mathrm{~nm}$ for May 2008. For this simulation, the model predicts the highest $N_{100}$ concentrations over the north-western part of continental Europe, and over southeastern Europe. For the baseline scenario in 2030, PMCAMx-UF predicts decreasing $N_{100}$ concentrations over whole Europe (Fig. 1f). The relative decrease in $\mathrm{PM}_{2.5}$ emissions is $40 \%$ for the baseline scenario according to IIASA (Table 1). Over large areas of Western Europe, the predicted decrease in $N_{100}$ is close to $40 \%$ (Fig. $2 \mathrm{~g}$ ). However, over southeastern Europe, and particularly the eastern Mediterranean, the predicted decrease in $N_{100}$ is higher, in general $60-70 \%$, which is more than can be explained by the reduction in primary aerosol emissions. The larger relative decrease in southeastern Europe can be explained by the role nucleation plays for $N_{100}$ in this region. Fountoukis et al. (2012) showed that in May 2008 new particle formation made the highest relative contribution $(\sim 20 \%)$ to $N_{100}$ over the eastern Mediterranean. They also reported that new particle formation could reduce by approximately $20 \%$ the concentration of particles larger than $100 \mathrm{~nm}$ in some areas, e.g. Spain. They explained this counterintuitive behaviour by reduced particle growth due to enhanced competition for condensable vapours in areas with high nucleation rates. Therefore, reduced $\mathrm{SO}_{2}$ emissions according to the baseline scenario, and the resulting decline in available $\mathrm{H}_{2} \mathrm{SO}_{4}$ for ternary nucleation, will reduce the $N_{100}$ concentrations the most over the eastern Mediterranean because new particle formation there plays a more important role as a source of $N_{100}$, compared to other parts of Europe. According to Amann et al. (2012), the relative $\mathrm{SO}_{2}$ emission reductions are predicted to be largest in countries in southeastern Europe (e.g. Bulgaria, Greece, and Romania). The fact that we have assumed equal emission reductions in all grid cells 
Table 2. Arithmetic mean and median percentage change in particle number concentration over the whole model domain between 2008 and 2030 for the different scenarios.

\begin{tabular}{lccc|ccc}
\hline & \multicolumn{3}{c|}{ Mean \% change } & \multicolumn{3}{c}{ Median \% change } \\
\cline { 2 - 7 } & $N_{\text {tot }}$ & $N_{10}$ & $N_{100}$ & $N_{\text {tot }}$ & $N_{10}$ & $N_{100}$ \\
\hline Baseline & -28 & -32 & -45 & -18 & -18 & -25 \\
MTFR & -40 & -44 & -56 & -25 & -26 & -35 \\
MCE & -48 & -51 & -60 & -30 & -31 & -40 \\
Baseline with changes & -33 & -32 & -38 & -17 & -16 & -19 \\
in trace gases only & & & & & & \\
\hline
\end{tabular}

means that the decrease in $N_{100}$ over southeastern Europe may be even larger than indicated in Fig. $2 \mathrm{~g}$.

It is worth pointing out that the condensational growth is most likely underestimated in some areas in this model study, due to the limited organic contribution to the growth of ultrafine particles in PMCAMx-UF, which leads our predictions of $N_{100}$ to be a lower estimate of $N_{100}$. As a result, the decrease in $N_{100}$ resulting from reduced condensational growth may be overpredicted in areas with large contributions from organic condensation to the growth.

For the MTFR scenario in 2030 (Fig. 1g), the model in general predicts a $60-80 \%$ decrease in $N_{100}$ over continental Europe, with the largest relative change still occurring over the eastern Mediterranean (Fig. 2h). The simulation of the MCE scenario in PMCAMx-UF (Fig. 1h) also gives a decrease of $60-80 \%$ in $N_{100}$ over continental Europe (Fig. 2i), but with more widespread areas of reductions $>70 \%$ than for the MTFR scenario.

\subsubsection{Relative importance of reduced primary aerosol emissions}

Table 2 shows the arithmetic mean and median percentage changes in number concentration for $N_{\text {tot }}, N_{10}$, and $N_{100}$, over the whole model domain (also including grid cells over the ocean) and the whole simulation period, for the different scenarios. An additional simulation was performed with emissions changed according to the baseline scenario 2030 with the exception of the $\mathrm{PM}_{2.5}$ emissions which were kept at their 2008 level. By comparing this simulation with the original baseline scenario simulation with reduced $\mathrm{PM}_{2.5}$ emissions, the relative importance of reduced primary aerosol emissions for the decreasing particle concentrations can be investigated. For particles larger than $100 \mathrm{~nm}$, the relative decrease in mean or median concentration for this simulation $(38 \%$ or $19 \%)$ is smaller than the corresponding decrease $(45 \%$ or $25 \%)$ for the original baseline scenario with reduced $\mathrm{PM}_{2.5}$ emissions (Table 2). This means that the reduced $\mathrm{PM}_{2.5}$ emissions associated with the original baseline scenario make a significant contribution to the decrease in $N_{100}$. However, for $N_{\text {tot }}$ the pattern is different. The (17\%) median percentage decrease in $N_{\text {tot }}$ for the baseline scenario with $\mathrm{PM}_{2.5}$ emissions at their 2008 level is similar to the $(18 \%)$ median percentage decrease for the baseline scenario with $\mathrm{PM}_{2.5}$ emissions reduced to their predicted 2030 level (Table 2). For the arithmetic mean change in concentration, the percentage decrease in $N_{\text {tot }}$ is even larger when $\mathrm{PM}_{2.5}$ emissions are kept at their 2008 level than when reducing them to their baseline 2030 level (Table 2), suggesting that reducing $\mathrm{PM}_{2.5}$ emissions could potentially result in a small increase in total particle number concentration on some occasions. The larger mean decrease in $N_{\text {tot }}$ when $\mathrm{PM}_{2.5}$ emissions are kept at their 2008 level, instead of being reduced, is most likely an effect of lower formation rates of new particles when the $\mathrm{PM}_{2.5}$ concentration is at a higher level, because these emitted particles compete for available condensable vapours and thereby suppress nucleation. Thus, the model predicts that reducing primary aerosol emissions will not significantly help to lower the number concentration of particles larger than $0.8 \mathrm{~nm}$. The pattern is similar for $N_{10}$. The reduction in $N_{10}$ for the case where $\mathrm{PM}_{2.5}$ is unchanged is similar to the corresponding reduction when $\mathrm{PM}_{2.5}$ is reduced according to the original baseline scenario. Hence, the dominating reduction in total number concentration over Europe seen in Fig. 2a is a result of reduced new particle formation due to reduced emissions of trace gases linked to nucleation.

\subsection{Diurnal cycles and number concentration variability}

Fountoukis et al. (2012) compared their modelled particle number concentrations with ground-based observations in May 2008 at seven different sites within the EUCAARI project: Ispra, Italy; Melpitz, Germany; Cabauw, the Netherlands; Aspvreten, Sweden; Hyytiälä, Finland; Mace Head, Ireland; and Vavihill, Sweden. These locations represent several different types of sites: Ispra is a polluted Mediterranean site; Melpitz can be regarded as representative of a regional central European site; Cabauw is located in a rural area in the western part of the Netherlands with nearby agricultural areas; Aspvreten is representative of the regional background in central Sweden; Hyytiälä represents the boreal background; Mace Head is located on the west coast of Ireland with a large marine influence from the Atlantic Ocean; and Vavihill is a Nordic background site with influence from central Europe. Here we compare diurnal cycles of particle number concentrations at these sites for the different emission scenarios.

Figure 4 shows predicted median diurnal cycles of $N_{\text {tot }}$ (Fig. 4a-g), $N_{10}$ (Fig. $4 \mathrm{~h}-\mathrm{n}$ ), and $N_{100}$ (Fig. 4o-u), for the seven locations, and for the different scenarios. Several of the locations in Fig. 4 have a pronounced peak in $N_{\text {tot }}$ during daytime. When these daytime peaks in $N_{\text {tot }}$ occur, $N_{\text {tot }}$ is much higher than $N_{10}$, indicating that these peaks are associated with new particle formation events. For most of the sites, PMCAMx-UF predicts higher daytime total number concentrations for the 2008 simulation than for the simulations of 

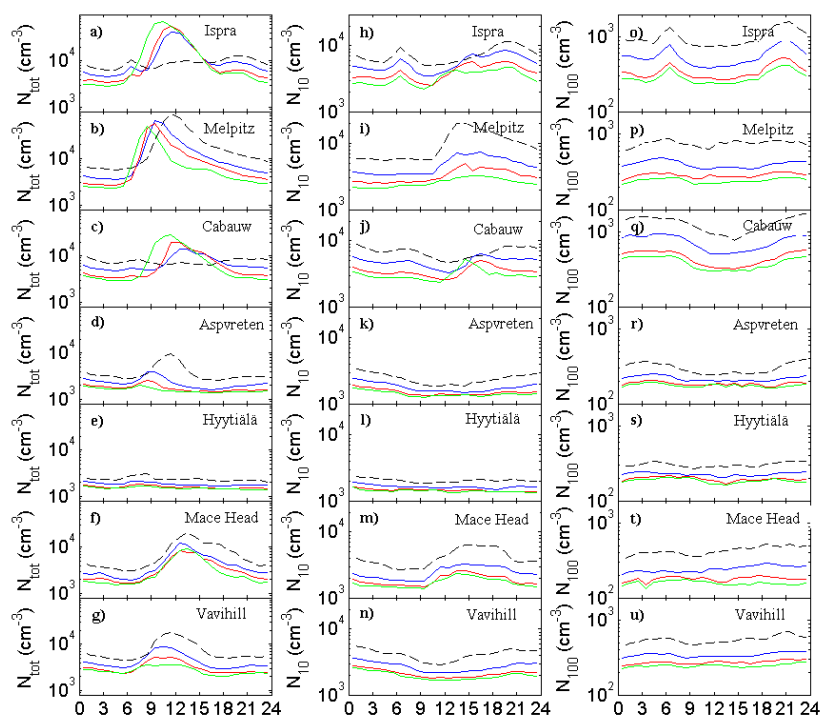

Fig. 4. Median diurnal cycles for $N_{\text {tot }}(\mathbf{a}-\mathbf{g}), N_{10}(\mathbf{h}-\mathbf{n})$, and $N_{100}$ (o-u) for May 2008 (black dashed lines), the baseline 2030 scenario (blue lines), the MTFR 2030 scenario (red lines), and the MCE 2030 scenario (green lines).

the 2030 scenarios. In general, the simulation of the MCE scenario gives the lowest daytime total number concentration, followed by the simulations of the MTFR scenario, and the baseline scenario. Hence, the more reduced the emissions, the lower the daytime $N_{\text {tot }}$ concentrations at most of the locations. The exceptions are Ispra (Fig. 4a) and Cabauw (Fig. 4c). At these locations, the simulation of the MCE scenario gives the highest daytime total number concentration, followed by the simulations of the MTFR scenario, the baseline scenario, and the simulation of May 2008. Hence, the more reduced the emissions at Ispra and Cabauw, the higher the $N_{\text {tot }}$ concentrations at these locations, contrary to the other sites. For the May 2008 simulation, there is not even a clear daytime peak in $N_{\text {tot }}$ at Ispra and Cabauw, indicating suppressed nucleation. Interestingly, Ispra and Cabauw are the two locations with the highest $N_{100}$ concentrations (Fig. 4o and q) of all the seven sites. For the simulations of May 2008, $N_{100}$ concentrations reach over $1000 \mathrm{~cm}^{-3}$ at Ispra and Cabauw, whereas the other sites (Fig. $4 p$ and Fig. $4 \mathrm{r}-\mathrm{u}$ ) have $N_{100}$ concentrations below $1000 \mathrm{~cm}^{-3}$. Thus, the high $N_{100}$ concentrations at Ispra and Cabauw suppress new particle formation in daytime. However, when emissions are reduced according to the future scenarios, concentrations of $N_{100}$ decrease which in turn lowers the condensation sink thereby enhancing daytime nucleation. Another effect in the simulations with reduced emissions according to the future scenarios is that new particle formation starts earlier in the morning. This is not the case only for Ispra and Cabauw, but can be seen also for Melpitz (Fig. 4b), Aspvreten (Fig. 4d), and Vavihill (Fig. 4g).
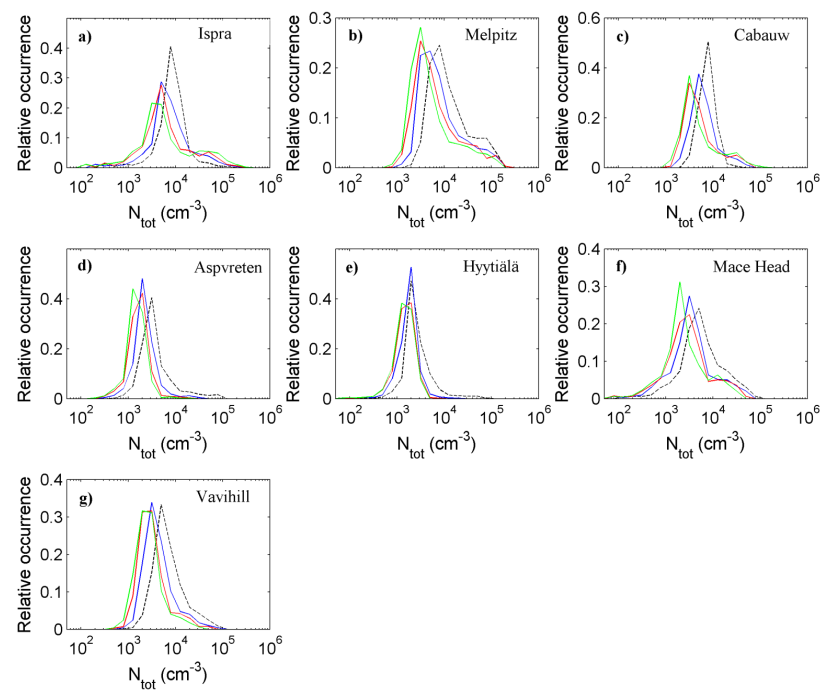

Fig. 5. Total number concentration probability distribution curves for May 2008 (black dashed lines), the baseline 2030 scenario (blue lines), the MTFR 2030 scenario (red lines), and the MCE 2030 scenario (green lines). The concentration bins are logarithmically equally distributed in the concentration axes (10 bins per decade).

The daytime concentration peaks are much less pronounced for $N_{10}$ than for $N_{\text {tot }}$, and at the locations where they are observed they occur later in the day because of the time required for condensational growth. The pattern of increasing daytime $N_{\text {tot }}$ concentrations when emissions are reduced, predicted for Ispra and Cabauw, is not evident for $N_{10}$ at these locations. The reason for this is suppressed condensational growth when $\mathrm{SO}_{2}$ and $\mathrm{NH}_{3}$ emissions have been reduced according to the IIASA emission scenarios. Hence, even though daytime nucleation may increase at locations with high $N_{100}$ concentrations when primary aerosol emissions are being reduced, the impact on $N_{10}$ concentrations from enhanced nucleation is predicted to be minor due to decreasing concentrations of condensable vapours.

Figure 5 shows predicted frequency distributions for $N_{\text {tot }}$ for the seven locations and for each scenario. The distributions for May 2008 are skewed towards higher concentrations at some of the locations, particularly in Melpitz (Fig. 5b) and Vavihill (Fig. 5g). This explains why the mean concentrations (Fig. 1a-d) are higher than the median concentrations (Fig. 3a-d) in many locations. The skewness is a result of nucleation events which may result in very high number concentrations. The probability distributions associated with the simulation of May 2008 are rather symmetric at Ispra (Fig. 5a) and Cabauw (Fig. 5c). However, at these locations the skewness of the frequency distributions is predicted to increase with reduced emissions. The MCE 2030 scenario, associated with the largest emission reductions, results in the most skewed distributions at these two locations, followed by the MTFR and the baseline scenarios. Even though the 

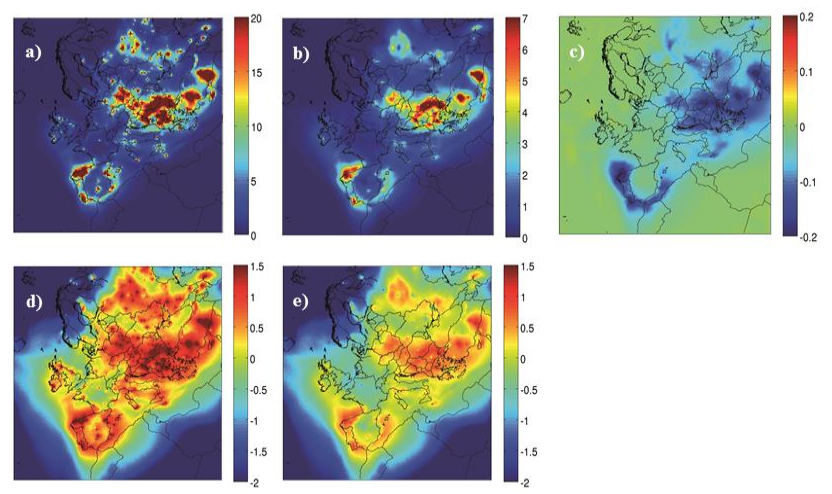

Fig. 6. Predicted average fractional increase in number concentration due to nucleation for the baseline 2030 scenario for $N_{\text {tot }}$ (a), $N_{10}$ (b), $N_{100}$ (c), $\log _{10}$ of the increase in $N_{\text {tot }}(\mathbf{d})$, and $\log _{10}$ of the increase in $N_{10}$ (e).

number concentration on average is predicted to decrease also at Ispra and Cabauw, the frequency of events with number concentrations higher than $20000 \mathrm{~cm}^{-3}$ is predicted to increase at these locations.

\subsection{Contribution of new particle formation to number concentrations}

The contribution of new particle formation to the particle number concentration can be investigated by turning off nucleation in PMCAMx-UF, and by comparing the output concentrations with those obtained when nucleation is turned on in the model. The fractional increase in concentration due to new particle formation can be defined as $f=\left(N_{N}-N_{0}\right) / N_{0}$, where $N_{N}$ and $N_{0}$ are the number concentrations with nucleation turned on and off, respectively. As presented by Fountoukis et al. (2012), the average fractional increases over the whole model domain and the whole simulation period for the May 2008 simulation are 3.0, 1.1, and 0.005 for $N_{\text {tot }}$, $N_{10}$, and $N_{100}$. The corresponding increases for the simulations of the baseline 2030 scenario are 2.8, 0.8 , and -0.04 , suggesting that the relative contribution of new particle formation to number concentrations may be slightly lower in the year 2030 than in 2008. Interestingly, the negative values for $N_{100}(-0.04)$ implies that the average $N_{100}$ concentration becomes even higher when nucleation is turned off than when it is turned on. Thus, the pattern that was discussed in Sect. 4.1, of a predicted negative impact of nucleation on $N_{100}$ concentrations in areas where particle formation rates are high, may increase in importance in the year 2030. The reduced emissions of $\mathrm{SO}_{2}$ and $\mathrm{NH}_{3}$ associated with the 2030 baseline scenario, and thereby lower amounts of condensable vapours, increase the competition for condensable vapours.

Figure 6 shows the average increases due to nucleation for the baseline scenario for $N_{\text {tot }}$ (a), $N_{10}$ (b), and $N_{100}$ (c). Figure 6d-e show $\log _{10}$ of the average increase in $N_{\text {tot }}$ (Fig. 6d), and in $N_{10}$ (Fig. 6e). The areas where the average increase in
$N_{\text {tot }}$ due to nucleation is largest are essentially the areas with the highest $N_{\text {tot }}$ concentrations (Fig. 1b) over eastern Europe and coastal areas in Spain and Portugal. In the same areas, the largest contribution of nucleation to $N_{10}$ is predicted. For $N_{100}$, new particle formation is either predicted to have a negative or zero impact on the concentration. As can be seen in Fig. 6c, the reducing impact of nucleation on $N_{100}$ concentrations is found in the areas with the highest total number concentrations (Fig. 1b), and where nucleation gives the largest fractional increase in $N_{\text {tot }}$ (Fig. 6a) and $N_{10}$ (Fig. 6b). As mentioned in Sect. 4.1, Fountoukis et al. (2012) found that new particle formation was predicted to give the largest fractional increase in $N_{100}$ over the eastern Mediterranean. The fact that new particle formation in the baseline scenario has a reducing impact on $N_{100}$ over the eastern Mediterranean (Fig. 6c) is likely an effect of the largely reduced $\mathrm{SO}_{2}$ concentrations in the baseline scenario (Table 1), resulting in suppressed condensational growth.

\subsection{What emission reductions are most important for reducing particle concentrations?}

The MTFR scenario explores to what extent emissions could be reduced further than the baseline scenario, through full application of available technical measures. In this section we investigate which of the emission reductions within the MTFR scenario would contribute the most to the decrease in particle number concentration over Europe. For this sensitivity study, we simulated the MTFR scenario as described in Table 1 , but with only one species reduced at a time. Hence, four simulations were performed with the emissions of one of $\mathrm{SO}_{2}, \mathrm{NH}_{3}, \mathrm{PM}_{2.5}$, and $\mathrm{NO}_{\mathrm{x}}$ changed, while the emissions of the other pollutants were kept unchanged. Table 3 shows the median change in $N_{\text {tot }}$ and $N_{10}$ over the whole model domain for each of the simulations. Clearly, reducing $\mathrm{SO}_{2}$ emissions is predicted to have a much larger impact on particle number concentrations than any of the other emission reductions. The $82 \%$ reduction in $\mathrm{SO}_{2}$ emissions reduces $N_{\text {tot }}$ by $24 \%$ and $N_{100}$ by $22 \%$. The $30 \%$ reduction in $\mathrm{NH}_{3}$ is predicted to only have minor impacts on the number concentrations $\left(-2.4 \%\right.$ for $N_{\text {tot }}$ and zero change for $\left.N_{100}\right)$. The $75 \%$ reduction in $\mathrm{NO}_{\mathrm{x}}$ emissions does not seem to play an important role. The $69 \%$ reduction in $\mathrm{PM}_{2.5}$ only reduces $N_{\text {tot }}$ by $2.4 \%$, but results in an $8.4 \%$ decrease in $N_{100}$.

The results of this sensitivity study indicate that reducing $\mathrm{SO}_{2}$ emissions is much more efficient than any other emission reduction for the total particle number concentration over Europe. However, reducing primary aerosol emissions will also help significantly in reducing $N_{100}$.

Many studies (e.g. Kapustin et al., 2006; Clarke et al., 2010) suggest the number concentration of particles with $D_{\mathrm{p}}>100 \mathrm{~nm}$ can serve as a surrogate for the CCN concentration. If using $N_{100}$ as a first estimate of the CCN concentration, one can conclude that reductions of $\mathrm{SO}_{2}$ and $\mathrm{PM}_{2.5}$ emissions, which are present in all three future emission 
Table 3. Median percentage change in particle number concentration over the whole model domain when one species is varied at the time within the MTFR scenario.

\begin{tabular}{lrr}
\hline & \multicolumn{2}{c}{ Median \% change } \\
\cline { 2 - 3 } & $N_{\text {tot }}$ & $N_{100}$ \\
\hline $\mathrm{SO}_{2}(-82 \%)$ & -24 & -22 \\
$\mathrm{NH}_{3}(-30 \%)$ & -2.4 & \pm 0 \\
$\mathrm{NO}_{\mathrm{x}}(-75 \%)$ & -0.6 & -3.0 \\
$\mathrm{PM}_{2.5}(-69 \%)$ & -2.4 & -8.4 \\
\hline
\end{tabular}

scenarios investigated in this study, will reduce the aerosol indirect effect over Europe. Furthermore, cutting $\mathrm{SO}_{2}$ emissions is predicted to play a more important role than reductions in $\mathrm{PM}_{2.5}$ emissions for the decrease in the aerosol indirect effect. However, the meteorological input for these simulations is from May, a time of the year when photochemistry plays an important role. For a time of the year with less incoming solar radiation, the relative importance of $\mathrm{SO}_{2}$ emissions for both $N_{\text {tot }}$ and $N_{100}$ would most likely be somewhat lower than in the results obtained here.

\subsection{Seasonal variations of primary aerosol emissions and nucleation}

According to the Pan-European anthropogenic Particle Number Emission Inventory (Denier van der Gon et al., 2009; Kulmala et al., 2011) primary emissions of black carbon, organics, and crustal material during the period 1-29 May 2008 (simulated in this study) in the European Union were 140 ktons, which is equivalent to $4.8 \mathrm{ktons} \mathrm{d}^{-1}$. This can be compared with the corresponding emissions during the period 25 February to 23 March in 2009 which were 165 ktons, equivalent to $6.1 \mathrm{ktons}^{-1}$. Larger particle emissions over Europe in the winter are partly a result of more wood and coal combustion during winter. Hence, the estimated contribution of primary emissions to particle number concentrations in this study represents a lower limit for primary emissions. Furthermore, nucleation is dependent on solar radiation, because the incoming solar radiation enhances the production of atmospheric $\mathrm{OH}$ and $\mathrm{H}_{2} \mathrm{SO}_{4}$. To investigate the role of meteorology in new particle formation we performed additional simulations with emission input data still being from the May period, but with meteorological input data from a period with less photochemical activity - January 2010. These simulations resulted in particle number concentrations that were approximately a factor of five lower than the number concentrations obtained in the original simulations. Since emissions were kept at the same levels as for the May simulations, the lower particle number concentrations obtained in the simulations with meteorology input from January are mainly a result of reduced new particle formation. Hence, the fact that we in this study have focused on a photochemically active period implies that the estimate of the contribution of new particle formation to the particle number concentration represents an upper limit for the influence of new particle formation. This also means that the sensitivity of the particle number concentration to $\mathrm{SO}_{2}$ emissions also probably represents an upper limit for this sensitivity.

\section{Summary and conclusions}

In this study we investigated how future scenarios of emissions of $\mathrm{SO}_{2}, \mathrm{NH}_{3}, \mathrm{NO}_{\mathrm{x}}$, and $\mathrm{PM}_{2.5}$ from the IIASA report by Amann et al. (2012) affect particle number concentrations over Europe in 2030, by performing simulations with PMCAMx-UF; a chemical transport model with detailed microphysics. The three different emission scenarios investigated in this study are: (1) a baseline scenario, which represents a best estimate of the emissions in 2030; (2) a Maximum Technically Feasible Reduction (MTFR) scenario, which represents technically possible emission reductions beyond those in the baseline scenario; and (3) a Maximum Control Efforts (MCE) scenario, which represents the largest possible emission cuts through application of all available technologies, rapid decarbonisation, and a change in the agricultural system to produce diets that include less meat. Our key results and main conclusions are:

1. For the baseline scenario, PMCAMx-UF predicts a $30-70 \%$ decrease in total particle number concentration between 2008 and 2030 over Europe. Reduced new particle formation is the dominating factor for this decline. Since the baseline scenario includes a $73 \%$ reduction in $\mathrm{SO}_{2}$ emissions but unchanged $\mathrm{NH}_{3}$ emissions, the decrease in new particle formation rates is due to reduced $\mathrm{H}_{2} \mathrm{SO}_{4}$ concentrations resulting from the decrease in $\mathrm{SO}_{2}$ emissions. For the other two scenarios, PMCAMx-UF predicts a decrease in $N_{\text {tot }}$ of $60-80 \%$.

2. The predicted reductions in $N_{100}$ are $40-70 \%$ for the baseline scenario, and 60-80\% for the other two scenarios. The largest reductions in $N_{100}$ were predicted in areas where new particle formation makes a large contribution to $N_{100}$.

3. The simulations of the different scenarios indicate that daytime new particle formation may locally increase between 2008 and 2030 in areas where $N_{100}$ concentrations are high. This is a result of enhanced new particle formation due to a reduced condensation sink following from the expected reduction in primary aerosol emissions in the future. However, the enhanced daytime concentration was only observed for $N_{\text {tot }}$, not for $N_{10}$, suggesting that concentrations of condensable vapours will be too low to grow the particles up to $10 \mathrm{~nm}$. 
4. The average fractional increases in number concentration due to nucleation for $N_{\text {tot }}, N_{10}$, and $N_{100}$ are predicted to decrease from 3.0, 1.1, and 0.005 in 2008, to $2.8,0.8$, and -0.04 in 2030 . Hence, on average nucleation is predicted to have a negative impact on $N_{100}$ in 2030. This negative impact of nucleation is predicted to be highest in areas where nucleation rates are high, likely because high nucleation rates enhances the competition for condensable vapours, which in turn may suppress condensational growth.

5. Reductions in $\mathrm{SO}_{2}$ emissions are predicted to have a much larger impact than any of the other emission reductions, on the total particle number concentration over Europe during at least photochemically active periods. Reductions in $\mathrm{PM}_{2.5}$ emissions are not predicted to play a significant role in reducing $N_{\text {tot }}$. For $N_{100}$, however, both reductions in $\mathrm{SO}_{2}$ and $\mathrm{PM}_{2.5}$ emissions contribute significantly to the decreasing concentrations, but also here $\mathrm{SO}_{2}$ plays the dominant role.

The predicted reductions in both $N_{\text {tot }}$ and $N_{100}$ between 2008 and 2030 will likely have important effects both in reducing the aerosol direct and indirect effects, and by decreasing the damaging effects of aerosol particles on human health in Europe. One limitation of this study is the lack of contribution of organic condensation to particle condensational growth in PMCAMx-UF, which likely results in underpredictions of $N_{100}$ in some areas, in particular areas with large biogenic influence. There is also some uncertainty regarding the role amines may play in nucleation, which is not included in the ternary $\mathrm{H}_{2} \mathrm{SO}_{4}-\mathrm{NH}_{3}-\mathrm{H}_{2} \mathrm{O}$ nucleation parameterization used here. However, since amines and ammonia often have similar sources, it is likely that the $\mathrm{NH}_{3}$ emission scenarios used in this study to some extent include the effect that trends in amine emissions may have on the change in new particle formation.

Acknowledgements. This project was supported by the European Research Council (ERC) ATMOGAIN (No. 278277) and the FP7 project PEGASOS (No. 265148). Computer resources for the model simulations were provided by the National Supercomputer Centre (NSC) in Linköping, Sweden. We would also like to thank Benjamin Murphy for model support.

Edited by: V.-M. Kerminen

\section{References}

Adams, P. J. and Seinfeld, J. H.: Predicting global aerosol size distributions in general circulation models, J. Geophys. Res., 107, 4370, doi:10.1029/2001JD001010, 2002.

Albrecht, B. A.: Aerosols, cloud microphysics, and fractional cloudiness, Science, 245, 1227-1230, 1989.

Amann, M., Borken-Kleefeld, J., Cofala, J., Heyes, C., Klimont, Z., Rafaj, P., Purohit, P., Schöpp, W., and Winiwarter, W.: Future emissions of air pollutants in Europe. Current legislation baseline and the scope for further reductions, IIASA, TSAP Report \#1, Version 1.0, 2012

Ball, S. M., Hanson, D. R., Eisele, F. L., and McMurry, P. H.: Laboratory studies of particle nucleation: initial results for $\mathrm{H}_{2} \mathrm{SO}_{4}$, $\mathrm{H}_{2} \mathrm{O}$, and $\mathrm{NH}_{3}$ vapors, J. Geophys. Res., 104, 23709-23718, 1999.

Bessagnet, B., Menut, L., Curci, G., Hodzic, A., Guillaume, B., Liousse, C., Moukhtar, S., Pun, B., Seigneur, C., and Schulz, M.: Regional modeling of carbonaceous aerosols over Europe-focus on secondary organic aerosols, J. Atmos. Chem., 61, 175-202, doi:10.1007/s10874-009-9129-2, 2008.

Clarke, A. and Kapustin, V.: Hemispheric aerosol vertical profiles: Anthropogenic impacts on optical depth and cloud nuclei, Science, 329, 1488-1492, 2010.

Coffman, D. J. and Hegg, D. A. A.: A preliminary study of the effect of ammonia on particle nucleation in the marine boundary layer, J. Geophys. Res., 100, 7147-7160, 1995.

Davidson, C. I., Phalen, R. F., and Solomon, P. A.: Airborne Particulate Matter and Human Health: A Review, Aerosol Sci. Tech., 39, 737-749, 2005.

Denier van der Gon, H. A. C., Visschedijk, A. J. H., Johansson, C., Hedberg Larsson, E., Harrison, R., and Beddows, D.: Sizeresolved pan European anthropogenic particle number inventory, EUCAARI Deliverable report D141 (available on request from EUCAARI project office), 2009.

Dusek, U., Frank, G. P., Hildebrandt, L., Curtius, J., Schneider, J., Walter, S., Chand, D., Drewnick, F., Hings, S., Jung, D., Borrmann, S., and Andreae, M. O.: Size matters more than chemistry for cloud-nucleating ability of aerosol particles, Science, 312, 1375-1378, doi:10.1126/science.1125261, 2006.

Fahey, K. M. and Pandis, S. N.: Optimizing model performance: Variable size resolution in cloud chemistry modelling, Atmos. Environ., 35, 4471-4478, doi:10.1016/S1352-2310(01)00224-2, 2001.

Fountoukis, C., Racherla, P. N., Denier van der Gon, H. A. C., Polymeneas, P., Charalampidis, P. E., Pilinis, C., Wiedensohler, A., Dall'Osto, M., O'Dowd, C., and Pandis, S. N.: Evaluation of a three-dimensional chemical transport model (PMCAMx) in the European domain during the EUCAARI May 2008 campaign, Atmos. Chem. Phys., 11, 10331-10347, doi:10.5194/acp11-10331-2011, 2011.

Fountoukis, C., Riipinen, I., Denier van der Gon, H. A. C., Charalampidis, P. E., Pilinis, C., Wiedensohler, A., O’Dowd, C., Putaud, J. P., Moerman, M., and Pandis, S. N.: Simulating ultrafine particle formation in Europe using a regional CTM: contribution of primary emissions versus secondary formation to aerosol number concentrations, Atmos. Chem. Phys., 12, 86638677, doi:10.5194/acp-12-8663-2012, 2012.

Gaydos, T. M., Stanier, C. O., and Pandis, S. N.: Modeling of in situ ultrafine atmospheric particle formation in the eastern United States, J. Geophys. Res., 110, D07S12, doi:10.1029/2004JD004683, 2005.

Gaydos, T., Pinder, R., Koo, B., Fahey, K., Yarwood, G., and Pandis, S. N.: Development and application of a three-dimensional Chemical Transport Model, PMCAMx, Atmos. Environ., 41, 2594-2611, 2007.

Intergovernmental Panel on Climate Change (IPCC): Climate Change 2007 - The Physical Science Basis: Contribution of 
Working Group I to the Fourth Assessment Report of the IPCC, Cambridge, Cambridge University Press, 2007.

Jung, J., Adams, P. J., and Pandis, S. N.: Simulating the size distribution and chemical composition of ultrafine particles during nucleation events, Atmos. Environ., 40, 2248-2259, doi:10.1016/j.atmosenv.2005.09.082, 2006.

Jung, J., Fountoukis, C., Adams, P. J., and Pandis, S. N.: Simulation of in situ ultrafine particle formation in the eastern United States using PMCAMx-UF, J. Geophys. Res., 115, D03203, doi:10.1029/2009JD012313, 2010.

Kapustin, V. N., Clarke, A. D., Schinozuka, Y., Howell, S., Brekhovskikh, V., Nakajima, T., and Higurashi, A.: On the determination of a cloud condensation nuclei from satellite: Challenges and possibilities, J. Geophys. Res., 111, D04202, doi:10.1029/2004JD005527, 2006.

Kirkby, J., Curtius, J., Almeida, J., Dunne, E., Duplissy, J., Ehrhart, S., Franchin, A., Gagné, S., Ickes, L., Kürten, A., Kupc, A., Metzger, A., Riccobono, F., Rondo, L., Schobesberger, S., Tsagkogeorgas, G., Wimmer, D., Amorim, A., Bianchi, F., Breitenlechner, M., David, A., Dommen, J., Downard, A., Ehn, M., Flagan, R. C., Haider, S., Hansel, A., Hauser, D., Jud, W., Junninen, H., Kreissl, F., Kvashin, A., Laaksonen, A., Lehtipalo, K., Lima, J., Lovejoy, E. R., Makhmutov, V., Mathot, S., Mikkilä, J., Minginette, P., Mogo, S., Nieminen, T., Onnela, A., Pereira, P., Petäjä, T., Schnitzhofer, R., Seinfeld, J. H., Sipilä, M., Stozhkov, Y., Stratmann, F., Tomé, A., Vanhanen, J., Viisanen, Y., Vrtala, A., Wagner, P. E., Walther, H., Weingartner, E., Wex, H., Winkler, P. M., Carslaw, K. S., Worsnop, D. R., Baltensperger, U., and Kulmala, M.: Role of sulphuric acid, ammonia and galactic cosmic rays in atmospheric aerosol nucleation, Nature, 476, 429-435, doi:10.1038/nature10343, 2011.

Kloster, S., Dentener, F., Feichter, J., Raes, F., van Aardenne, J., Roeckner, E., Lohmann, U., Stier, P., and Swart, R.: Influence of future air pollution mitigation strategies on total aerosol radiative forcing, Atmos. Chem. Phys., 8, 6405-6437, doi:10.5194/acp-86405-2008, 2008.

Kuang, C., McMurry, P. H., McCormick, A. V., and Eisele, F. L.: Dependence of nucleation rates on sulfuric acid vapor concentration in diverse atmospheric locations, J. Geophys. Res., 113, D10209, doi:10.1029/2007JD009253, 2008.

Kulmala, M., Vehkamäki, H., Petäjä, T., Dal Maso, M., Lauri, A., Kerminen, V.-M., Birmili, W., and McMurry, P. H.: Formation and growth rates of ultrafine atmospheric particles: A review of observations, J. Aerosol Sci., 35, 143-176, doi:10.1016/j.jaerosci.2003.10.003, 2004.

Kulmala, M., Lehtinen, K. E. J., and Laaksonen, A.: Cluster activation theory as an explanation of the linear dependence between formation rate of $3 \mathrm{~nm}$ particles and sulphuric acid concentration, Atmos. Chem. Phys., 6, 787-793, doi:10.5194/acp-6-787-2006, 2006.

Kulmala, M., Asmi, A., Lappalainen, H. K., Baltensperger, U., Brenguier, J.-L., Facchini, M. C., Hansson, H.-C., Hov, Ø., O'Dowd, C. D., Pöschl, U., Wiedensohler, A., Boers, R., Boucher, O., de Leeuw, G., Denier van der Gon, H. A. C., Feichter, J., Krejci, R., Laj, P., Lihavainen, H., Lohmann, U., McFiggans, G., Mentel, T., Pilinis, C., Riipinen, I., Schulz, M., Stohl, A., Swietlicki, E., Vignati, E., Alves, C., Amann, M., Ammann, M., Arabas, S., Artaxo, P., Baars, H., Beddows, D. C. S., Bergström, R., Beukes, J. P., Bilde, M., Burkhart, J. F.,
Canonaco, F., Clegg, S. L., Coe, H., Crumeyrolle, S., D’Anna, B., Decesari, S., Gilardoni, S., Fischer, M., Fjaeraa, A. M., Fountoukis, C., George, C., Gomes, L., Halloran, P., Hamburger, T., Harrison, R. M., Herrmann, H., Hoffmann, T., Hoose, C., Hu, M., Hyvärinen, A., Hõrrak, U., Iinuma, Y., Iversen, T., Josipovic, M., Kanakidou, M., Kiendler-Scharr, A., Kirkevåg, A., Kiss, G., Klimont, Z., Kolmonen, P., Komppula, M., Kristjánsson, J.-E., Laakso, L., Laaksonen, A., Labonnote, L., Lanz, V. A., Lehtinen, K. E. J., Rizzo, L. V., Makkonen, R., Manninen, H. E., McMeeking, G., Merikanto, J., Minikin, A., Mirme, S., Morgan, W. T., Nemitz, E., O’Donnell, D., Panwar, T. S., Pawlowska, H., Petzold, A., Pienaar, J. J., Pio, C., Plass-Duelmer, C., Prévôt, A. S. H., Pryor, S., Reddington, C. L., Roberts, G., Rosenfeld, D., Schwarz, J., Seland, Ø., Sellegri, K., Shen, X. J., Shiraiwa, M., Siebert, H., Sierau, B., Simpson, D., Sun, J. Y., Topping, D., Tunved, P., Vaattovaara, P., Vakkari, V., Veefkind, J. P., Visschedijk, A., Vuollekoski, H., Vuolo, R., Wehner, B., Wildt, J., Woodward, S., Worsnop, D. R., van Zadelhoff, G.-J., Zardini, A. A., Zhang, K., van Zyl, P. G., Kerminen, V.-M., S Carslaw, K., and Pandis, S. N.: General overview: European Integrated project on Aerosol Cloud Climate and Air Quality interactions (EUCAARI) - integrating aerosol research from nano to global scales, Atmos. Chem. Phys., 11, 13061-13143, doi:10.5194/acp11-13061-2011, 2011.

Lamarque, J.-F., Kyle, G. P., Meinshausen, M., Riahi, K., Smith, S. J., van Vuuren, D. P., Conley, A. J., and Vitt, F.: Global and regional evolution of short-lived radiatively-active gases and aerosols in the Representative Concentration Pathways, Climatic Change, 109, 191-212, doi:10.1007/s10584-011-0155-0, 2011.

Lovejoy, E. R., Curtius, J., and Froyd, K. D.: Atmospheric ioninduced nucleation of sulfuric acid and water, J. Geophys. Res., 109, D08204, doi:10.1029/2003JD004460, 2004.

Makkonen, R., Asmi, A., Kerminen, V.-M., Boy, M., Arneth, A., Hari, P., and Kulmala, M.: Air pollution control and decreasing new particle formation lead to strong climate warming, Atmos. Chem. Phys., 12, 1515-1524, doi:10.5194/acp-12-15152012, 2012.

McMurry, P. and Friedlander, S.: New particle formation in the presence of an aerosol, Atmos. Environ., 13, 1635-1651, 1979.

Merikanto, J., Napari, I., Vehkamaki, H, Anttila, T., and Kulmala, M.: New parameterization of sulfuric acid-ammonia-water ternary nucleation rates at tropospheric conditions, J. Geophys. Res., 112, D15207, doi:10.1029/2006JD007977, 2007.

Murphy, S. M., Sorooshian, A., Kroll, J. H., Ng, N. L., Chhabra, P., Tong, C., Surratt, J. D., Knipping, E., Flagan, R. C., and Seinfeld, J. H.: Secondary aerosol formation from atmospheric reactions of aliphatic amines, Atmos. Chem. Phys., 7, 2313-2337, doi:10.5194/acp-7-2313-2007, 2007.

Napari, I., Noppel, M., Vehkamaki, H., and Kulmala, M.: Parameterization of ternary nucleation rates for $\mathrm{H}_{2} \mathrm{SO}_{4}-\mathrm{NH}_{3}-\mathrm{H}_{2} \mathrm{O}$ vapors, J. Geophys. Res., 107, 4381, doi:10.1029/2002JD002132, 2002.

Oberdörster, G., Gelein, R., Ferin, J., and Weiss, B.: Association of Particulate Air Pollution and Acute Mortality: Involvement of Ultrafine Particles, Inhal. Toxicol., 71, 111-124, 1995.

Paasonen, P., Nieminen, T., Asmi, E., Manninen, H. E., Petäjä, T., Plass-Dülmer, C., Flentje, H., Birmili, W., Wiedensohler, A., Hõrrak, U., Metzger, A., Hamed, A., Laaksonen, A., Facchini, M. C., Kerminen, V.-M., and Kulmala, M.: On the roles of sul- 
phuric acid and low-volatility organic vapours in the initial steps of atmospheric new particle formation, Atmos. Chem. Phys., 10, 11223-11242, doi:10.5194/acp-10-11223-2010, 2010.

Peters, A., Wichmann, E., Tuch, T., Heinrich, J., and Heyder, J: Respiratory Effects are Associated with the Number of Ultrafine Particles, Am. J. Resp. Crit. Care, 155, 1376-1383, 1997.

Pierce, J. R. and Adams, P. J.: A computationally efficient aerosol nucleation/condensation method: Pseudosteadystate sulfuric acid, Aerosol Sci. Tech., 43, 216-226, doi:10.1080/02786820802587896, 2009.

Pilinis, C., Capaldo, K. P., Nenes, A., and Pandis, S. N.: MADMa new multicomponent aerosol dynamics model, Aerosol Sci. Tech., 32, 482-502, 2000.

Pope III, C. A. and Dockery, D. W.: Health Effects of Fine Particulate Air Pollution: Lines that Connect, J. Air Waste Manage., 56, 709-742, 2006.

Raes, F., Janssens, A., and Vandingenen, R.: The role of ion-induced aerosol formation in the lower atmosphere, J. Aerosol Sci., 17, 466-470, doi:10.1016/0021-8502(86)90135-7, 1986.

Riccobono, F., Rondo, L., Sipilä, M., Barmet, P., Curtius, J., Dommen, J., Ehn, M., Ehrhart, S., Kulmala, M., Kürten, A., Mikkilä, J., Paasonen, P., Petäjä, T., Weingartner, E., and Baltensperger, U.: Contribution of sulfuric acid and oxidized organic compounds to particle formation and growth, Atmos. Chem. Phys., 12, 9427-9439, doi:10.5194/acp-12-9427-2012, 2012.

Riipinen, I., Sihto, S.-L., Kulmala, M., Arnold, F., Dal Maso, M., Birmili, W., Saarnio, K., Teinilä, K., Kerminen, V.-M., Laaksonen, A., and Lehtinen, K. E. J.: Connections between atmospheric sulphuric acid and new particle formation during QUEST III-IV campaigns in Heidelberg and Hyytiälä, Atmos. Chem. Phys., 7, 1899-1914, doi:10.5194/acp-7-1899-2007, 2007.

Schell, B., Ackermann, I. J., Hass, H., Binkowski, F. S., and Ebel, A.: Modeling the formation of secondary organic aerosol within a comprehensive air quality model system, J. Geophys. Res., 106, 28275-28293, doi:10.1029/2001JD000384, 2001.

Shi, Q., Davidovits, P., Jayne, J. T., Worsnop, D. R., and Kolb, C. E.: Uptake of Gas-Phase Ammonia. 1. Uptake by aqueous surfaces as a function of pH, J. Phys. Chem. A, 103, 8812-8823, 1999.

Sihto, S.-L., Kulmala, M., Kerminen, V.-M., Dal Maso, M., Petäjä, T., Riipinen, I., Korhonen, H., Arnold, F., Janson, R., Boy, M., Laaksonen, A., and Lehtinen, K. E. J.: Atmospheric sulphuric acid and aerosol formation: implications from atmospheric measurements for nucleation and early growth mechanisms, Atmos. Chem. Phys., 6, 4079-4091, doi:10.5194/acp-6-4079-2006, 2006.

Simpson, D., Yttri, K. E., Klimont, Z., Kupiainen, K., Caseiro, A., Gelencser, A., Pio, C., Puxbaum, H., and Legrand, M.: Modeling carbonaceous aerosol over Europe: Analysis of the CARBOSOL and EMEP EC/OC campaigns, J. Geophys. Res., 112, D23S14, doi:10.1029/2006JD008158, 2007.
Skamarock, W. C., Klemp, J. B., Dudhia, J., Gill, D. O., Barker, D. M., Wang, W., and Powers, J. G.: A Description of the Advanced Research WRF Version 2, NCAR Technical Note (http://www. mmm.ucar.edu/wrf/users/docs/arw_v2.pdf), 2005.

Sorokin, A. and Arnold, F.: Laboratory study of cluster ions formation in $\mathrm{H}_{2} \mathrm{SO}_{4}-\mathrm{H}_{2} \mathrm{O}$ system: Implications for threshold concentration of gaseous $\mathrm{H}_{2} \mathrm{SO}_{4}$ and ion-induced nucleation kinetics, Atmos. Environ., 41, 3740-3747, 2007.

Smith, J. N., Barsanti, K. C., Friedli, H. R., Ehn, M., Kulmala, M., Collins, D. R., Scheckman, J. H., Williams, B. J., and McMurry, P. H.: Observations of aminium salts in atmospheric nanoparticles and possible climatic implications, P. Natl. Acad. Sci., 107, 6634-6639, 2010.

Stier, P., Feichter, J., Roeckner, E., Kloster, S., and Esch, M.: The evolution of the global aerosol system in a transient climate simulation from 1860 to 2100, Atmos. Chem. Phys., 6, 3059-3076, doi:10.5194/acp-6-3059-2006, 2006.

Swartz, E., Shi, Q., Davidovits, P., Jayne, J. T., Worsnop, D. R., and Kolb, C. E.: Uptake of Gas-Phase Ammonia. 2. Uptake by sulfuric acid surfaces, J. Phys. Chem. A, 103, 8824-8833, 1999.

Twomey, S.: The influence of pollution on the shortwave albedo of clouds, J. Atmos. Sci., 34, 1149-1152, 1977.

Visschedijk, A. J. H., Zandveld, P., and Denier van der Gon, H. A. C.: TNO Report 2007 A R0233/B: A high resolution gridded European emission database for the EU integrated project GEMS, Netherlands, Organization for Applied Scientific Research, 2007.

Weber, R. J., McMurry, P. H., Eisele, F. L., and Tanner, D. J.: Measurements of expected nucleation precursor species and 3500nm diameter particles at Mauna Loa observatory, Hawaii, J. Atmos. Sci., 52, 2242-2257, 1995.

Wexler, A. S., Lurmann, F. W., and Seinfeld, J. H.: Modelling urban and regional aerosols-I. Model development, Atmos. Environ. 28, 531-546, 1994.

Yu, F.: Effect of ammonia on new particle formation: A kinetic H2SO4-H2O-NH3 nucleation model constrained by laboratory measurements, J. Geophys. Res., 111, D01204, doi:10.1029/2005JD005968, 2006a.

Yu, F.: From molecular clusters to nanoparticles: second-generation ion-mediated nucleation model, Atmos. Chem. Phys., 6, 51935211, doi:10.5194/acp-6-5193-2006, 2006b.

Zhang, Y., McMurry, P. H., Yu, F., and Jacobson, M. Z.: A comparative study of nucleation parameterizations: 1. Examination and evaluation of the formulations, J. Geophys. Res., 115, D20212, doi:10.1029/2010JD014150, 2010. 